\title{
Physical activity improves protein utilization in young men
}

\author{
BY GAIL E. BUTTERFIELD AND DORIS H. CALLOWAY \\ Department of Nutritional Sciences, University of California, Berkeley, \\ California 94720, USA
}

(Received 10 March 1983 - Accepted 8 September 1983)

1. Protein utilization in young men under circumstances of one or two periods of work and both adequate and surfeit energy intake was determined by nitrogen balance; protein intake was constant at the FAO/WHO (1973) safe level $(0.57 \mathrm{~g} / \mathrm{kg}$ body-weight).

2. Physical activity affected protein utilization negatively by increasing sweat and faecal $\mathrm{N}$ losses, and positively by supporting increased energy intake.

3. Efficiency with which surfeit energy improved $\mathbf{N}$ utilization (mg $\mathbf{N}$ retained/added $\mathrm{kJ}$ ) was greater under circumstances of increased activity.

4. Changes in body composition as determined by total body potassium and hydrostatic weighing supported the $\mathrm{N}$ retention values.

After a century of quiescence, the issue of a relationship between physical activity or work and protein requirement has resurfaced. This resurgence of interest is a consequence of two major lines of evidence: discovery of significant metabolism of the branched-chain amino acids in resting and working muscle, and reports of protein-related responses to chronic exercise in man. The latter line includes reports of increased $\mathrm{N}$ retention with increased protein intake by active men (Consolazio et al. 1975), diminished haemoglobin levels in men during training (Yoshimura, 1961), and inadequacy of the FAO/WHO (1973) safe level of protein intake for men doing isometric exercises (Torun et al. 1977).

In principle the first consideration, amino acid participation in work metabolism, would be relevant to the question of protein requirements if a net catabolism of protein could be demonstrated in the physically active individual. To date no such net catabolism has been demonstrated. The second line of evidence, while appearing conclusive, is actually derived from experiments made difficult to interpret by their design. In some studies, the work assigned involved training which might impose a short-term protein demand for the construction of muscle tissue and, perhaps, increased blood volume. In some, sweat losses were not measured and, with the increased sweating that would accompany increased physical activity, spuriously positive $\mathbf{N}$ balances would be expected. Finally, most studies are confounded by differences in energy intake leading to a variety of energy balances accompanying the work. These potential imbalances may have occurred as a result of increased voluntary intake, experimentally imposed constancy of intake in the face of increased need, or inappropriate augmentation of intake in association with work.

To illuminate these relationships and to determine if physical activity does influence protein utilization, we measured $\mathrm{N}$ retention in men assigned two different amounts of exercise of equivalent load, such that any training effect would be minimized. Energy intake was either sufficient to maintain body-weight or in excess under both conditions of activity. The findings to be reported here show that both activity and excess energy intake favour $\mathrm{N}$ retention. 
Table. 1. Description of subjects participating in the study

\begin{tabular}{|c|c|c|c|c|c|c|}
\hline \multirow[b]{2}{*}{ Subject no. } & \multirow{2}{*}{$\begin{array}{c}\text { Age } \\
\text { (years) }\end{array}$} & \multirow{2}{*}{$\begin{array}{l}\text { Height } \\
\text { (m) }\end{array}$} & \multirow{2}{*}{$\begin{array}{c}\text { Initial } \\
\text { wt } \\
(\mathrm{kg})\end{array}$} & \multirow{2}{*}{$\begin{array}{c}\text { Surface } \\
\text { area } \\
\left(\mathrm{m}^{2}\right)\end{array}$} & \multicolumn{2}{|c|}{$\begin{array}{l}\text { Energy requirement } \\
(\mathrm{kJ}(\mathrm{kcal}) / \mathrm{kg} \text { per } \mathrm{d})\end{array}$} \\
\hline & & & & & Basal & Maintenance* \\
\hline 4201 & 25 & 1.66 & $64 \cdot 7$ & 1.76 & $102(24 \cdot 5)$ & $163(38.9)$ \\
\hline 4202 & 24 & 1.68 & $60 \cdot 9$ & 1.69 & $96(23.0)$ & $186(44 \cdot 5)$ \\
\hline 4203 & 27 & 1.83 & 75.8 & 1.99 & $90(21 \cdot 6)$ & $173(41 \cdot 4)$ \\
\hline 4204 & 24 & 1.77 & $71 \cdot 9$ & 1.93 & $97(23 \cdot 1)$ & $166(39.8)$ \\
\hline 4205 & 24 & 1.69 & $64 \cdot 5$ & 1.74 & $104(24 \cdot 8)$ & $170(40 \cdot 7)$ \\
\hline 4206 & 25 & 1.73 & $68 \cdot 8$ & 1.85 & $94(22 \cdot 5)$ & $169(40 \cdot 5)$ \\
\hline Mean & 24.8 & 1.73 & 67.8 & 1.83 & $97(23 \cdot 3)$ & $171(41.0)$ \\
\hline SD & 1.2 & 0.06 & $5 \cdot 5$ & $0 \cdot 12$ & $5(1 \cdot 2)$ & $8(1.9)$ \\
\hline
\end{tabular}

* Energy required to maintain stable body-weight at $1.0 \mathrm{X}$, referred to as $1.0 \mathrm{E}$ (for details, see p. 173).

Table 2. Experimental design

\begin{tabular}{|c|c|c|c|c|c|}
\hline $\begin{array}{l}\text { Period } \\
\text { no.* }\end{array}$ & $\begin{array}{c}\text { Protein } \\
(\mathrm{g} / \mathrm{kg})\end{array}$ & $\begin{array}{l}\text { Energy } \\
\text { intake }+\end{array}$ & $\begin{array}{l}\text { Exercise } \\
\text { regimen§ }\end{array}$ & $\begin{array}{c}\text { Intended energy } \\
\text { balance }\end{array}$ & $\begin{array}{c}\text { Period } \\
\text { description }\end{array}$ \\
\hline $1 \dagger$ & 0.57 & $1 \cdot 0$ & 1.0 & 0 & $\begin{array}{l}\text { Stabilization: } \\
\text { I.0E, } 1.0 \mathrm{X}\end{array}$ \\
\hline 2 & 0.57 & $1 \cdot 0$ & $1 \cdot 0$ & 0 & $1.0 \mathrm{E}, 1.0 \mathrm{X}$ \\
\hline 3 & 0.57 & $1 \cdot 15$ & 1.0 & $+0 \cdot 15$ & $1 \cdot 15 \mathrm{E}, 1.0 \mathrm{X}$ \\
\hline 4 & 0.57 & $1 \cdot 15$ & $1 \cdot 15$ & 0 & $1 \cdot 15 \mathrm{E}, 1 \cdot 15 \mathrm{X}$ \\
\hline 5 & 0.57 & $1 \cdot 3$ & $1 \cdot 15$ & $+0 \cdot 15$ & $1 \cdot 3 \mathrm{E}, 1 \cdot 15 \mathrm{X}$ \\
\hline
\end{tabular}

E, energy; X, exercise (for details, see below).

* Each period was of $18 \mathrm{~d}$ duration.

$\dagger$ Preceded by a standardization or pretest period in which protein intake was $1.0 \mathrm{~g} / \mathrm{kg}$.

$\$ 1 \cdot 0 \mathrm{E}=$ energy intake required for constant body-weight as established in period $1,171 \cdot 4$ (SD 8.1) kJ (41.0 (SD $1.9) \mathrm{kcal}) / \mathrm{kg}$ per $\mathrm{d} ; 1.15 \mathrm{E}=15 \%$ above the $1.0 \mathrm{E}$ level.

$\S 1.0=1 \mathrm{~h}$ treadmill at $4.8 \mathrm{~km} / \mathrm{h}(3 \mathrm{miles} / \mathrm{h}), 10 \%$ grade; $1.15 \mathrm{X}=1.0 \mathrm{X}$ plus $1 \mathrm{~h}$ bicycle pedalling at individually fixed load equal to $15 \%$ of $1.0 \mathrm{E}$.

\section{EXPERIMENT A L}

\section{Subjects and experimental design}

Six male non-smokers aged 24-27 years (Table 1) were recruited from a local community. All were in good health as determined by physical examination, routine blood and urine analyses and dietary history. They were housed for $108 \mathrm{~d}$ in the residential metabolic unit at the University of California and left the unit only when necessary to perform tests. At such time, they were accompanied by a member of staff. Environmental conditions and general procedures followed were similar to those in previous studies (Calloway \& Margen, 1971).

Throughout the study, $1 \mathrm{~h}$ of treadmill walking at $4.8 \mathrm{~km} / \mathrm{h}(3 \mathrm{miles} / \mathrm{h}), 10 \%$ grade, was assigned in three $20 \mathrm{~min}$ bouts daily (standard exercise 1.0X). Energy intake and assigned exercise were varied to produce four treatments which included periods with and without both surfeit energy and added work (for details, see Table 2).

During an $18 \mathrm{~d}$ pre-period, the men were given $1.0 \mathrm{~g}$ egg-white protein $/ \mathrm{kg}$ body-weight, and energy intake was varied to approximate the amount required by each man to maintain 
a stable body-weight. In period 1, protein intake was lowered to $0.57 \mathrm{~g} / \mathrm{kg}$ body-weight (the FAO/WHO (1973) safe level of protein) and energy intake was further adjusted to establish maintenance energy requirements $(1 \cdot 0 \mathrm{E})$. This period allowed adequate time for adaptation to the lowered protein intake, which remained at the FAO/WHO (1973) safe level throughout the rest of the study. Period 2 was the control condition of energy balance with light exercise $(1 \cdot 0 \mathrm{E}+1 \cdot 0 \mathrm{X})$.

Subsequently, energy intake was increased to 1.15 or 1.3 times the $1.0 \mathrm{E}$ level. In periods 4 and 5 , two $30 \mathrm{~min}$ bouts of daily bicycle work $(700 \mathrm{Kp} ; 60 \mathrm{rev} . / \mathrm{min})$ were added to produce an assigned energy output of $1.0 \mathrm{X}$ plus 0.15 of the $1.0 \mathrm{E}$ value for each man. As a consequence of these manipulations, energy intake in periods 3 and 5 was greater than energy output; in period 4, energy intake and output were balanced, as in period 2, but the total energy intake was greater.

In the case of both the treadmill and bicycle, the time of exercise was staggered according to a $6 \mathrm{~d}$ cycle so that each day an individual exercised at a different time relative to meals. This complex scheduling was adopted to eliminate any effect that timing of meals relative to exercise might have on protein utilization (Cuthbertson et al. 1937). Energy expenditure outside the assigned work consisted of light or sedentary activities which were held as constant as possible throughout the study.

\section{Diet}

A purified diet adequate in all known essential nutrients was provided as a basic formula supplying $2.52 \mathrm{~g} \mathrm{~N} / 4.18 \mathrm{MJ}$ (1000 kcal) of diet plus vitamin-mineral supplements. Appropriate amounts of energy supplements were added to the basic formula (for details of diet composition see Table 3) to meet the constraints of the outlined regimen (for individual energy intakes for each period see Table 4). Carbohydrate supplied approximately $65 \%$ of the non-protein energy intake and fat provided approximately 35\%. Total intake was divided into three equal meals given at $08.30,13.30$ and 18.30 hours. One beverage and one treat (hard candy or sugarless chewing gum) were provided at each meal.

Composites of the total food and nutrient intake/d for the largest and the smallest man were prepared by the dietitian each time the diet was changed. These composites were analysed for $\mathbf{N}$ using the micro-Kjeldahl method and the values thus obtained were used in calculating the actual $\mathbf{N}$ intake $\left(\mathrm{N}_{\mathrm{I}}\right)$ of each subject during each period.

\section{Samples and measurements}

The general health of the men was monitored daily by the nursing staff who determined the pre-rising temperature, heart rate and respiratory rate of the men. Every morning after voiding, the men were weighed to the nearest $0 \cdot 1 \mathrm{~kg}$.

Urine collections $(24 \mathrm{~h})$ were made daily. The daily urine was weighed and qualitatively tested for glucose, protein and acetone. Specific gravity and $\mathrm{pH}$ were measured and portions were diluted to volume. Total urinary N (TUN; micro-Kjeldahl analysis) and creatinine (automated alkaline picric acid method) were measured on these samples. Urine composites ( $3 \mathrm{~d})$ were made and analysed for urea (automated carbamido-dicetyl method, Coulombe $\&$ Faureau, 1963).

Faeces were collected quantitatively as $3 \mathrm{~d}$ pools and homogenized in a colloid mill with a known volume of dilute acid. Faecal dry weight (vacuum-oven method) and $\mathrm{N}$ content were determined.

Sweat N (SN) collections ( $3 \mathrm{~d}$ ) were made once during each metabolic period according to methods previously described (Calloway et al. 1971). Basal metabolic rate (BMR) and energy expenditure at rest and while performing various activities were determined by indirect calorimetry (Consolazio et al. 1963a); these findings will be reported in detail elsewhere. 
Table 3. Diet composition ( $\mathrm{g}$ component/4.18 MJ (1000 kcal))

\begin{tabular}{|c|c|c|}
\hline Component & $\begin{array}{c}\text { Basic } \\
\text { formula }\end{array}$ & $\begin{array}{l}\text { Energy } \\
\text { formula }\end{array}$ \\
\hline Water & 137.48 & 289.01 \\
\hline Egg albumen* & 19.79 & - \\
\hline Maltodextrins $\dagger$ & $70 \cdot 04$ & 75.64 \\
\hline Maize starch $\ddagger$ & 70.04 & $75 \cdot 64$ \\
\hline Sucrose§ & $18 \cdot 43$ & 19.90 \\
\hline Cottonseed oil\| & $36 \cdot 86$ & $39 \cdot 81$ \\
\hline Calcium carbonateq & $0 \cdot 10$ & - \\
\hline Magnesium oxide & 0.22 & - \\
\hline Potassium chloride $\uparrow$ & $1 \cdot 72$ & - \\
\hline Calcium hypophosphatef & $1 \cdot 11$ & - \\
\hline Sodium chloride & $2 \cdot 13$ & - \\
\hline Calcium citrate** & 0.40 & - \\
\hline Biotin $\dagger \dagger$ & 0.80 & - \\
\hline
\end{tabular}

* Spray-dried egg white; Seymour Foods, Inc.

$\S$ Grain Processing Company.

$\ddagger$ CPC International.

$\S \mathrm{C}$ and $\mathrm{H}$.

T Mallinckrodt.

** $\mathrm{MC} / \mathrm{B}$.

†† Cal Biochem.

Vitamin and microminerals were supplied, in tablet form, each day in the following amounts: retinol, $600 \mu \mathrm{g}$; ergocalciferol, $5 \mu \mathrm{g}$; $\alpha$-tocopherol, $23.3 \mathrm{mg}$; folic acid, $0.5 \mathrm{mg}$; nicotinamide, $20.0 \mathrm{mg}$; calcium pantothenate, $10.0 \mathrm{mg}$; thiamin, $2.0 \mathrm{mg}$; riboflavin, $3.0 \mathrm{mg}$; pyridoxine, $5.0 \mathrm{mg} ; \mathrm{B}_{12}, 2.0 \mu \mathrm{g}$; biotin, $0.05 \mathrm{mg}$; vitamin $\mathrm{K}, 1.0 \mathrm{mg}$; vitamin C, $50 \mathrm{mg}$; iron, $10.0 \mathrm{mg}$ (as ferric sulphate); copper, $2.0 \mathrm{mg}$ (as cupric chloride); zinc, $15.0 \mathrm{mg}$ (as zinc sulphate); manganese, $4.9 \mathrm{mg}$ (as manganese sulphate); molybdenum, $0.24 \mathrm{~g}$ (as sodium molybdate); chromium, $0.5 \mathrm{mg}$ (as chromium sulphate); selenium, $0.011 \mathrm{mg}$ (as sodium selenate); aluminium, $4.8 \mathrm{mg}$ (as aluminium potassium sulphate); iodine, $0.15 \mathrm{mg}$ (as potassium iodine); fluoride, $1.0 \mathrm{mg}$ (as sodium fluoride). Vitamin pills, batch M431A, Mills Laboratory, Inc., Eikhart, Indiana; trace minerals pills, batch 2JX162, Stayner Company, Berkeley, California. $1 \mathrm{~g}$ of choline chloride (Nulife) was also given daily. Non-digestible carbohydrate was added to the formula as methyl cellulose and raffinose $(2: 1 \mathrm{w} / \mathrm{w}$; total fibre intake $6 \mathrm{~g} / \mathrm{d})$. Each man also received daily two hard candies (Life Savers), one stick of sugarless chewing gum (Trident), two cups of decaffeinated coffee (Sanka) and one cup of instant tea (Lipton).

Table 4. Total energy intake $(M J(k c a l) / d)$ for young men under two conditions of energy balance and work*

\begin{tabular}{|c|c|c|c|}
\hline \multirow[b]{2}{*}{$\begin{array}{l}\text { Level of exercise } \dagger . . . \\
\text { Subject no. }\end{array}$} & \multicolumn{3}{|c|}{ Period } \\
\hline & $\begin{array}{c}1.0 \mathrm{E} \\
1 \text { and } 2\end{array}$ & $\begin{array}{l}1 \cdot 15 \mathrm{E} \\
3 \text { and } 4\end{array}$ & $\begin{array}{c}1.3 E \\
5\end{array}$ \\
\hline 4201 & $10 \cdot 76(2572)$ & $12.36(2954)$ & $13.96(3336)$ \\
\hline 4202 & $11 \cdot 22(2681)$ & $12.89(3080)$ & $14.56(3479)$ \\
\hline 4203 & $13.00(3108)$ & $14.94(3570)$ & $16.87(4032)$ \\
\hline 4204 & $12 \cdot 18(2911)$ & $13.99(3343)$ & $15.80(3776)$ \\
\hline 4205 & $10.85(2593)$ & $12.46(2978)$ & $14 \cdot 39(3440)$ \\
\hline 4206 & $11.74(2807)$ & $13.49(3224)$ & $15.23(3641)$ \\
\hline
\end{tabular}

* Values represent energy intake at end of metabolic period.

$\dagger$ For details, see p. 173. 
Body composition was assessed at least twice each period throughout the study by measuring body density by the method of underwater weighing (Consolazio et al. 1963a). The residual lung volume of each individual was determined using the $\mathrm{N}$ washout method (Wilmore, 1969) and total body fat was computed from body density using the formula of Siri (1966). Total body potassium (TBK; mmol) was estimated once during each metabolic period by measuring the individuals' total body ${ }^{40} \mathrm{~K}$ in a $2 \mathrm{Pi}$ whole-body scintillation counter (Environmental Physiology Laboratory, University of California, Berkeley).

\section{Calculations}

Urine values were excluded on the basis of exceptional creatinine content of a given sample, confirmed by repeated analysis. Stable urinary values were assumed to have been attained by the last $8 \mathrm{~d}$ of each period. Urea excretion reported represents the mean of the last three $3 \mathrm{~d}$ urine pools of each metabolic period. $\mathrm{N}$ balances were computed for each man for each day from his daily urinary $\mathrm{N}$, his mean faecal $\mathrm{N}(\mathrm{FN}$ ) for each $18 \mathrm{~d}$ metabolic period, his SN losses for each period and the laboratory value for the total $\mathrm{N}$ content of his diet for each period. The mean of six stable balance values for each man for each period was used in computing the mean period balance. Final balances were also corrected for blood losses, assuming a loss of $32 \mathrm{mg} \mathrm{N} / \mathrm{g}$ blood drawn (Calloway et al. 1971), spread equally over the period subsequent to the blood drawing (i.e. restoration assumed to be equal and complete in $18 \mathrm{~d}$ ). Individuals were assumed to be in $\mathrm{N}$ equilibrium if the mean $\mathrm{N}$ balance thus computed was $0.15 \mathrm{mg} \mathrm{N}$, as this represents the losses not accounted for in this experiment (miscellaneous losses of hair, nails, body secretions and nitrate-N (Kurzer \& Calloway, 1981)).

All values were analysed for significant subject and treatment effects and significant interactions using the ANOVA program of the Statistical Package for the Social Sciences (SPSS). If the results of the ANOVA analysis indicated there was no significant interaction of subject and treatment, the analysis was perused for significant treatment effects. If there was a significant treatment effect, a pairwise comparison of period means using the Dunn multiple range test (Kirk, 1968) was done to identify the significantly different periods. If the results of the ANOVA analysis indicated there were significant subject-by-treatment interactions, the response of each subject was studied separately, both graphically and by pairwise comparison of individual means using the Dunn multiple range test. Statistical significance was set at the 0.05 level.

\section{Ethical considerations}

The experimental design and protocol for this experiment were approved by the Committee for the Protection of Human Subjects, University of California, Berkeley. The purpose, nature, risks and benefits of the experiment were described to potential subjects, and they were given the opportunity to ask and to have answered all pertinent questions before consenting to participate.

\section{RESULTS \\ Body-weight}

Fig. 1 presents the daily body-weights for all men throughout the study.

The goal of the first treatment period was to determine for each man the energy intake required to maintain a constant body-weight, defined as energy balance. All men initially received $167 \mathrm{~kJ} / \mathrm{kg}$ per d $(40 \mathrm{kcal} / \mathrm{kg}$ per d) and body-weight was monitored. For three of the men (nos. 4203, 4205 and 4206) this intake was adequate; for the other three men, this 


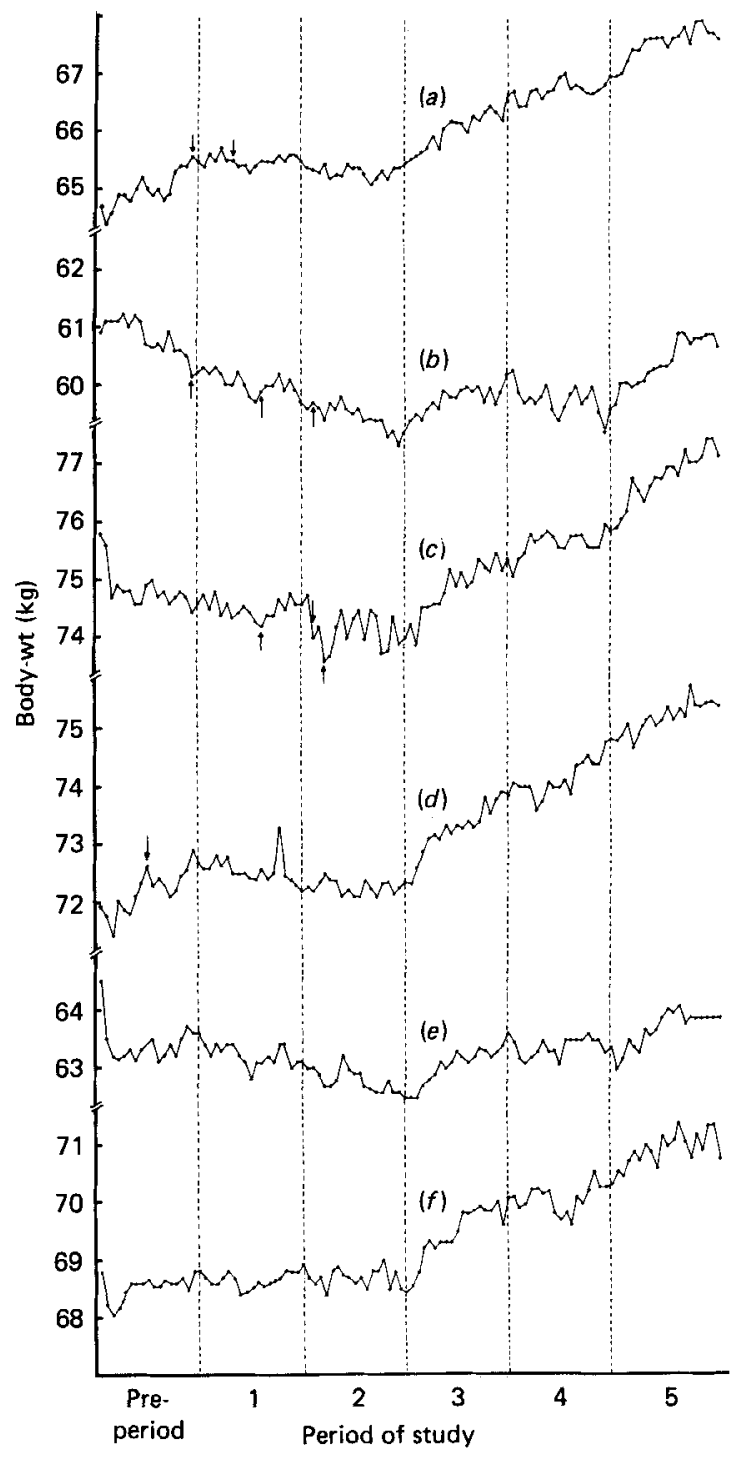

Fig. 1. Daily body-weights for six young men under two conditions of energy balance and work. (:) Demarcation between metabolic periods: (1) $1.0 \mathrm{E}+1.0 \mathrm{X}$, (2) $1.0 \mathrm{E}+1.0 \mathrm{X}$, (3) $1.15 \mathrm{E}+1.0 \mathrm{X}$, (4) $1 \cdot 15 \mathrm{E}+1 \cdot 15 \mathrm{X},(5) 1 \cdot 30 \mathrm{E}+1 \cdot 15 \mathrm{X}$. Subject no. (a) 4201, (b) 4202, (c) 4203, (d) 4204, (e) 4205, $(f) 4206$. $(\downarrow)$ Day and direction of change in energy intake. E, energy; $X$, exercise; $1.0 \mathrm{E}$, energy intake to maintain stable body-weight (for details, see p. 173).

intake was either in excess (nos. 4201 and 4204) or insufficient (no. 4202) to maintain energy balance, and intakes were adjusted appropriately to those indicated in Table 4 . The true energy requirement for stable body-weight in subject no. 4202 was never determined. Four men (nos. 4202, 4203, 4204 and 4205) had a slight, but constant, decrease in body-weight throughout period 2. The rate of weight loss seen in Fig. 1 and indicated by the slope of regression lines drawn through the values $(17-30 \mathrm{~g} / \mathrm{d})$ is of a magnitude one might expect in individuals who are in slight negative $\mathrm{N}$ balance (Inoue et al. 1973).

The mean (with SD) energy intake required to maintain energy balance in the confined conditions of the metabolic unit was determined to be $171(8) \mathrm{kJ} / \mathrm{kg}$ per d (41.0(1.9) $\mathrm{kcal} / \mathrm{kg}$ 
Table 5. Individual faecal $(F N, g / d) \ddagger$, sweat $(S N, g / d)$ and blood $(B N, g / d) \S$ nitrogen values for young men under two conditions of energy balance and work

\begin{tabular}{|c|c|c|c|c|c|c|c|c|c|}
\hline \multirow[b]{2}{*}{ Period no. } & \multirow{2}{*}{$\begin{array}{c}\text { Treatment } \\
\text { and measurement }\end{array}$} & \multicolumn{6}{|c|}{ Subject no. } & \multirow[b]{2}{*}{ Mean } & \multirow[b]{2}{*}{ SD } \\
\hline & & 4201 & 4202 & 4203 & 4204 & 4205 & 4206 & & \\
\hline \multirow[t]{4}{*}{1} & $\begin{array}{r}\text { Stabilization } \\
1 \cdot 0 \mathrm{E}, 1 \cdot 0 \mathrm{X}\end{array}$ & & & & & & & & \\
\hline & FN & 0.73 & 0.62 & 0.84 & 0.56 & $0 \cdot 78$ & 0.85 & 0.73 & $0 \cdot 12$ \\
\hline & SN & $0 \cdot 19$ & 0.26 & 0.28 & $0 \cdot 19$ & 0.20 & $0 \cdot 23$ & 0.23 & 0.04 \\
\hline & $\mathrm{BN}$ & 0.05 & 0.05 & 0.05 & 0.06 & 0.06 & $0 \cdot 06$ & 0.06 & 0.01 \\
\hline \multirow[t]{4}{*}{2} & $1.0 \mathrm{E}, 1.0 \mathrm{X}$ & & & & & & & & \\
\hline & FN & 0.82 & 0.64 & 0.81 & 0.50 & 0.70 & 0.88 & 0.73 & $0 \cdot 14$ \\
\hline & SN & $0 \cdot 19$ & $0 \cdot 26$ & 0.28 & 0.19 & $0 \cdot 20$ & 0.23 & 0.23 & 0.04 \\
\hline & $\mathrm{BN}$ & 0.05 & 0.05 & 0.05 & 0.06 & 0.06 & 0.06 & 0.06 & 0.01 \\
\hline \multirow[t]{4}{*}{3} & $1.15 \mathrm{E}, 1.0 \mathrm{X}$ & & & & & & & & \\
\hline & FN & $0 \cdot 81$ & 0.69 & 0.98 & 0.43 & 0.87 & 0.99 & 0.80 & $0 \cdot 27$ \\
\hline & SN & $0 \cdot 21$ & $0 \cdot 29$ & 0.24 & $0 \cdot 22$ & 0.23 & $0 \cdot 17$ & $0 \cdot 23$ & 0.04 \\
\hline & $\mathrm{BN}$ & 0.12 & 0.09 & $0 \cdot 10$ & $0 \cdot 10$ & 0.10 & $0 \cdot 10$ & $0 \cdot 10$ & 0.01 \\
\hline \multirow[t]{4}{*}{4} & $1 \cdot 15 \mathrm{E}, 1 \cdot 15 \mathrm{X}$ & & & & & & & & \\
\hline & FN & 0.89 & 0.77 & $1 \cdot 14$ & 0.64 & 0.81 & 1.08 & 0.89 & 0.33 \\
\hline & SN & 0.28 & 0.34 & 0.30 & 0.25 & 0.31 & 0.24 & 0.29 & $0.04 t$ \\
\hline & BN & $0 \cdot 15$ & $0 \cdot 11$ & 0.12 & $0 \cdot 13$ & 0.12 & $0 \cdot 12$ & $0 \cdot 13$ & 0.01 \\
\hline \multirow[t]{4}{*}{5} & $1 \cdot 3 \mathrm{E}, 1 \cdot 15 \mathrm{X}$ & & & & & & & & \\
\hline & FN & $1 \cdot 11$ & 0.69 & $1 \cdot 13$ & 0.92 & 0.80 & $1 \cdot 20$ & 0.97 & 0.35 \\
\hline & SN & $0 \cdot 26$ & $0 \cdot 36$ & $0 \cdot 30$ & $0 \cdot 31$ & $0 \cdot 30$ & $0 \cdot 27$ & $0 \cdot 30$ & $0.03^{*}$ \\
\hline & BN & $0 \cdot 13$ & 0.09 & $0 \cdot 13$ & 0.13 & $0 \cdot 12$ & $0 \cdot 11$ & $0 \cdot 12$ & 0.02 \\
\hline
\end{tabular}

E, energy; X, exercise (for details, see p. 172).

* SN; period $3 v$. period $5 ; P<0.05$.

$\dagger$ SN; period $4 v$. period 5; not significant.

$\$$ Mean of all values for each period.

$\S 32 \mathrm{mg} \mathrm{N} / \mathrm{g}$ blood lost at end of previous period evenly divided by days of period.

per d), a value very close to that previously stated to be required to maintain energy balance in similar subjects in this facility (172 (12) $\mathrm{kJ} / \mathrm{kg}$ per d or $41.2(2.9) \mathrm{kcal} / \mathrm{kg}$ per d; Calloway, 1975). No further alteration in $1.0 \mathrm{E}$ was made throughout the rest of the experiment, so that $\mathrm{N}$ balances determined at the end of each period were collected under constant conditions.

With the increase in energy intake to $1.15 \mathrm{E}$, or $196(10) \mathrm{kJ} / \mathrm{kg}$ per d $(46.8(2.4) \mathrm{kcal} / \mathrm{kg}$ per d) all men experienced a gradual increase in body-weight. The mean rate of increase determined from slopes of regression lines calculated from the results was $59 \cdot 3(15.9) \mathrm{g} / \mathrm{d}$. Energy intake was in excess by a mean (with SD) of $1.73(0.13) \mathrm{MJ} / \mathrm{d}(413(31) \mathrm{kcal} / \mathrm{d})$ and the mean calculated rate of conversion of excess energy to tissue was $28.0 \mathrm{~kJ} / \mathrm{g}(6.69 \mathrm{kcal} / \mathrm{g})$.

The attempt to re-establish energy balance by increasing physical activity in period 4 was essentially accomplished, after the first week of the period, for three of the six men. The slight weight change during the early phase of the period for subject nos. 4201 and 4203 $(0.3$ and $0.5 \mathrm{~kg}$ respectively) may represent either a training effect of the additional activity, including glycogen accumulation with water retention, or an inadequate increase in energy expenditure; based on body composition determinations neither of these men experienced a detectable increase in lean body mass. Subject no. 4204 consistently failed to follow the experimental bicycle procedure exactly as outlined and he continued to gain weight.

Energy intake was finally increased to $1.3 \mathrm{E}$ or $218(12) \mathrm{kJ} / \mathrm{kg}$ per d $(52.1(3.0) \mathrm{kcal} / \mathrm{kg}$ 
Table 6. Nitrogen intake $\left(N_{I}, g / d\right)$, total urinary $N(T U N, g / d) \ddagger$, urinary urea $N(U U N$, $g / d) \S$ and $N$ balance $(N B a l, g / d) \|$ in young men under two conditions of energy balance and work

\begin{tabular}{|c|c|c|c|c|c|c|c|c|c|}
\hline \multirow[b]{2}{*}{ Period no. } & \multirow{2}{*}{$\begin{array}{l}\text { Treatment and } \\
\text { measurement }\end{array}$} & \multicolumn{6}{|c|}{ Subject no. } & \multirow[b]{2}{*}{ Mean } & \multirow[b]{2}{*}{ SD } \\
\hline & & 4201 & 4202 & 4203 & 4204 & 4205 & 4206 & & \\
\hline \multirow[t]{5}{*}{1} & $\begin{array}{l}\text { Stabilization, } \\
1.0 \mathrm{E}, 1.0 \mathrm{X}\end{array}$ & & & & & & & & \\
\hline & $\mathrm{N}_{\mathrm{I}}$ & $6 \cdot 45$ & 5.98 & $7 \cdot 19$ & $7 \cdot 08$ & $6 \cdot 19$ & $6 \cdot 68$ & $6 \cdot 59$ & $0 \cdot 48$ \\
\hline & TUN & $5 \cdot 54$ & $4 \cdot 80$ & 6.67 & 6.90 & $5 \cdot 26$ & 5.88 & $5 \cdot 84$ & 0.82 \\
\hline & UUN & $4 \cdot 27$ & 3.59 & 4.96 & $4 \cdot 95$ & 4.03 & 4.96 & $4 \cdot 46$ & 0.59 \\
\hline & NBal & -0.07 & 0.25 & -0.65 & -0.62 & $-0 \cdot 11$ & $-0 \cdot 34$ & -0.26 & $0 \cdot 35$ \\
\hline \multirow[t]{5}{*}{2} & $1.0 \mathrm{E}, 1.0 \mathrm{X}$ & & & & & & & & \\
\hline & $\mathrm{N}_{\mathrm{I}}$ & 6.45 & 5.98 & $7 \cdot 19$ & 7.08 & $6 \cdot 19$ & 6.68 & 6.59 & 0.48 \\
\hline & TUN & $5 \cdot 32$ & 4.92 & 6.65 & 6.92 & $5 \cdot 26$ & $5 \cdot 40$ & 5.74 & 0.83 \\
\hline & UUN & 3.85 & 3.56 & 4.99 & $5 \cdot 40$ & 3.96 & 3.82 & $4 \cdot 26$ & 0.74 \\
\hline & NBal & $0 \cdot 11$ & $0 \cdot 12$ & -0.60 & -0.62 & -0.07 & $0 \cdot 12$ & $-0 \cdot 16$ & $0 \cdot 36$ \\
\hline \multirow[t]{5}{*}{3} & $1 \cdot 15 \mathrm{E}, 1 \cdot 0 \mathrm{X}$ & & & & & & & & \\
\hline & $\mathrm{N}_{\mathrm{I}}$ & $6 \cdot 43$ & 5.97 & $7 \cdot 18$ & 7.07 & $6 \cdot 18$ & $6 \cdot 67$ & $6 \cdot 58$ & 0.48 \\
\hline & TUN & $4 \cdot 62$ & $4 \cdot 63$ & 5.71 & $6 \cdot 16$ & 4.89 & $4 \cdot 75$ & $5 \cdot 12$ & $0.65 \dagger$ \\
\hline & UUN & 2.99 & $3 \cdot 29$ & 4.00 & $4 \cdot 53$ & 3.49 & $3 \cdot 15$ & $3 \cdot 58$ & $0.58 t$ \\
\hline & NBal & 0.68 & 0.27 & $0 \cdot 15$ & $0 \cdot 15$ & $0 \cdot 10$ & 0.66 & 0.34 & $0.27^{*+}$ \\
\hline \multirow[t]{5}{*}{4} & $1 \cdot 15 \mathrm{E}, 1 \cdot 15 \mathrm{X}$ & & & & & & & & \\
\hline & $\mathrm{N}_{\mathrm{I}}$ & $6 \cdot 43$ & 5.97 & $7 \cdot 18$ & 7.07 & $6 \cdot 18$ & 6.67 & $6 \cdot 58$ & 0.48 \\
\hline & TUN & 4.97 & $4 \cdot 50$ & 6.02 & $6 \cdot 19$ & $5 \cdot 34$ & $4 \cdot 78$ & $5 \cdot 30$ & 0.68 \\
\hline & UUN & $3 \cdot 27$ & 2.95 & $4 \cdot 26$ & $4 \cdot 50$ & 3.78 & 2.99 & 3.63 & 0.66 \\
\hline & NBal & $0 \cdot 14$ & 0.25 & $-0 \cdot 40$ & $-0 \cdot 14$ & $-0 \cdot 39$ & 0.45 & -0.02 & $0.35 * \dagger$ \\
\hline \multirow[t]{5}{*}{5} & $1 \cdot 3 \mathrm{E}, 1 \cdot 15 \mathrm{X}$ & & & & & & & & \\
\hline & $\mathrm{N}_{\mathrm{I}}$ & $6 \cdot 46$ & 6.00 & $7 \cdot 22$ & $7 \cdot 10$ & $6 \cdot 22$ & $6 \cdot 70$ & $6 \cdot 62$ & 0.48 \\
\hline & TUN & 3.98 & $3 \cdot 70$ & 4.87 & 5.03 & $4 \cdot 37$ & $4 \cdot 15$ & $4 \cdot 35$ & 0.52 \\
\hline & UUN & $2 \cdot 51$ & $2 \cdot 40$ & $3 \cdot 26$ & $3 \cdot 54$ & 2.98 & $2 \cdot 25$ & 2.82 & 0.52 \\
\hline & NBal & 0.98 & $1 \cdot 17$ & 0.79 & 0.71 & 0.62 & 0.97 & 0.87 & 0.20 \\
\hline
\end{tabular}

E, energy; $X$, excercise (for details, see p. 172).

* NBal; period 3 or period $4 v$. period 2, $P<0.05$.

$\dagger$ TUN, UUN and NBal; period 3 or period $4 v$. period $5, P<0.05$.

$\$$ Mean of 6 of last $8 \mathrm{~d}$ of each metabolic period.

$\$$ Mean of last three $3 \mathrm{~d}$ pools.

$\|$ Computed as [ $\mathrm{N}$ intake - (urinary $\mathrm{N}+$ sweat $\mathrm{N}+$ faecal $\mathrm{N}+$ blood losses)]. Mean of 6 of last $8 \mathrm{~d}$ of each metabolic period.

per d), and all men again experienced an increase in body-weight. The mean (with SD) rate of increase during the last period of the experiment (48 (17) g/d) was slightly lower than that in the other period of surfeit energy consumption ( $59(16) \mathrm{g} / \mathrm{d})$, and the mean calculated rate of conversion of excess energy to tissue was $39 \cdot 1 \mathrm{~kJ} / \mathrm{g}(9 \cdot 39 \mathrm{kcal} / \mathrm{g})$.

\section{$N$ excretion}

Mean FN (Table 5) appears to have increased slightly in response to an increase in energy intake and increased physical activity. This apparent treatment effect was supported by statistical analysis, although no significantly different period could be identified due to the individual variation in FN response to the dietary treatments. Consequently, individual period mean $\mathrm{FN}$ was used in calculating the $\mathrm{N}$ balances below.

Mean SN (Table 5) did not change significantly with the increase in energy intake (period $2 v$. period 3) but the increase in mean SN with the addition of exercise in period 4 was 


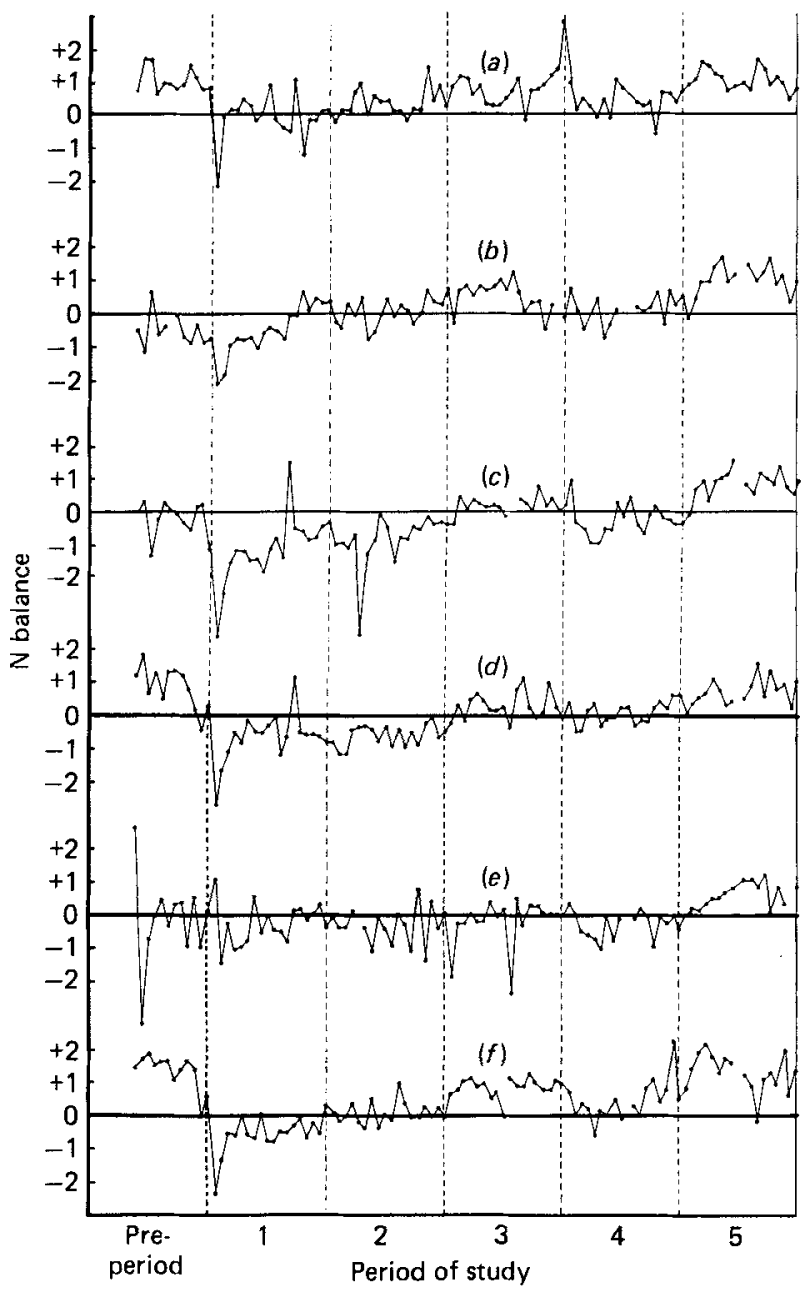

Fig. 2. Daily nitrogen balance ( $N$ intake - (sweat $N+$ faecal $N+$ total urinary $N$ )) for six young men under two conditions of energy balance and work. (:) Demarcation between metabolic periods: (1) $1 \cdot 0 \mathrm{E}+1 \cdot 0 \mathrm{X}$, (2) $1 \cdot 0 \mathrm{E}+1 \cdot 0 \mathrm{X}$, (3) $1 \cdot 15 \mathrm{E}+1 \cdot 0 \mathrm{X}$, (4) $1 \cdot 15 \mathrm{E}+1 \cdot 15 \mathrm{X}$, (5) $1 \cdot 3 \mathrm{E}+1 \cdot 15 \mathrm{X}$. Subject no. (a) $4201,(b) 4202$, (c) 4203, (d) 4204, (e) 4205, (f) 4206. N intake constant at $0.57 \mathrm{~g} / \mathrm{kg}$ body-weight, with exception of pre-period. E, energy; X, exercise; $1.0 \mathrm{E}$, energy intake to maintain stable body-weight (for details, see p. 172).

statistically significant. Statistical comparison of the mean $\mathrm{SN}$ in the first three periods (no added exercise) with that in the last two periods (increased exercise) showed a significant difference associated with exercise.

TUN and urinary urea-N (UUN, Table 6) responded similarly to all treatments. Both TUN and UUN decreased with the addition of surfeit energy (period $2 v$. period 3; period $4 v$. period 5). Comparing effects of exercise under energy balance conditions, values at the higher activity level (period 4) were not significantly different from those at the lower activity level (period 2), although there was a tendency for TUN to be lower at the higher level of energy expenditure. The mean levels of both measurements were significantly decreased in the period of surfeit energy intake with added exercise (period 5) when compared with a period of surfeit energy at lower activity (period 3). 
Table 7. Total body potassium ( $T B K$, mmol) as determined by ${ }^{40} \mathrm{~K}$ counting and lean body mass* $(L B M, k g)$ as determined by underwater weighing in young men under two conditions of energy balance and work

\begin{tabular}{|c|c|c|c|c|c|c|c|c|c|}
\hline \multirow[b]{2}{*}{ Period no. } & \multirow{2}{*}{$\begin{array}{l}\text { Treatment and } \\
\text { measurement }\end{array}$} & \multicolumn{6}{|c|}{ Subject no. } & \multirow[b]{2}{*}{ Mean } & \multirow[b]{2}{*}{ SD } \\
\hline & & 4201 & 4202 & 4203 & 4204 & 4205 & 4206 & & \\
\hline \multirow[t]{3}{*}{1} & $\begin{array}{c}\text { Stabilization, } \\
1.0 \mathrm{E}, 1.0 \mathrm{X}\end{array}$ & & & & & & & & \\
\hline & TBK & 3527 & 3235 & 4386 & 4066 & 3609 & 4036 & 3810 & 424 \\
\hline & LBM & 51.66 & 48.85 & 62.73 & $62 \cdot 15$ & $50 \cdot 72$ & $58 \cdot 41$ & $55 \cdot 75$ & $6 \cdot 11$ \\
\hline \multirow[t]{3}{*}{2} & $1.0 \mathrm{E}, 1.0 \mathrm{X}$ & & & & & & & & \\
\hline & TBK & 3563 & 3179 & 4396 & 4026 & 3491 & 4013 & 3778 & 444 \\
\hline & LBM & $51 \cdot 23$ & $48 \cdot 58$ & $62 \cdot 89 \dagger$ & $62 \cdot 32$ & $50 \cdot 39$ & $57 \cdot 55$ & $55 \cdot 49$ & $6 \cdot 29$ \\
\hline \multirow[t]{3}{*}{3} & $1.15 \mathrm{E}, 1.0 \mathrm{X}$ & & & & & & & & \\
\hline & TBK & 3670 & 3233 & 4389 & 4128 & 3542 & 4018 & 3830 & 425 \\
\hline & LBM & 51.56 & $49 \cdot 47$ & 62.47 & $61 \cdot 45$ & 50.08 & 56.61 & $55 \cdot 26$ & $5 \cdot 78$ \\
\hline \multirow[t]{3}{*}{4} & $1 \cdot 15 \mathrm{E}, 1 \cdot 15 \mathrm{X}$ & & & & & & & & \\
\hline & TBK & 3637 & 3179 & 4488 & 4105 & 3514 & 4110 & 3839 & 479 \\
\hline & LBM & 51.95 & $49 \cdot 90$ & $62 \cdot 93$ & $63 \cdot 20$ & 49.89 & $57 \cdot 54$ & $55 \cdot 90$ & $7 \cdot 48$ \\
\hline \multirow[t]{3}{*}{5} & $1 \cdot 3 \mathrm{E}, 1 \cdot 15 \mathrm{X}$ & & & & & & & & \\
\hline & TBK & 3734 & 3258 & 4593 & 4179 & 3588 & 4105 & 3901 & 477 \\
\hline & LBM & $51 \cdot 47$ & $50 \cdot 76$ & 63.57 & $62 \cdot 25$ & $50 \cdot 43$ & 57.92 & 57.07 & 5.98 \\
\hline
\end{tabular}

E, energy; X, exercise (for details, see p. 172).

* Calculated as total body-weight - kg fat, the latter being calculated from Siri's (1966) formula for \% body fat:

$$
\left(\frac{4.95}{\text { density }}-4.5\right) \times 100 \text {. }
$$

$\uparrow$ Measurement made on day 45 instead of day 53.

\section{$N$ balance}

Fig. 2 depicts the daily $\mathrm{N}$ balance $\left(\mathrm{N}_{\mathrm{I}}-(\mathrm{TUN}+\mathrm{FN}+\mathrm{SN})\right.$ ) for each man. All men demonstrated a transient (2-12 d) negative $\mathrm{N}$ balance at the beginning of period 1 when protein intake was reduced from 1.0 to $0.57 \mathrm{~g} / \mathrm{kg}$ body-weight per $\mathrm{d}$. After adjusting, four men (nos. 4201, 4202, 4205 and 4206) appeared to have achieved $\mathrm{N}$ equilibrium at the marginal $\mathrm{N}$ intake; two men (nos. 4203 and 4204) were definitely not in $\mathrm{N}$ equilibrium.

$\mathrm{N}$ retention increased with the shift to surfeit energy intake (period $2 v$. period 3), four men (nos. 4201, 4202, 4204 and 4206) going into positive balance, and two (nos. 4203 and 4205 ) coming apparently into equilibrium, while all increased body-weight.

With the addition of exercise and return to energy balance (period $3 v$. period 4), all men responded initially with a dip in $\mathrm{N}$ balance which returned towards the pre-exercise level within 8-12 d. In most cases the value of $\mathrm{N}$ balance achieved near the end of the period was higher than that achieved in period 2, a period of similar energy balance with a lower energy intake and activity.

With the increase in energy intake to $1 \cdot 3 \mathrm{E}$ (period 5), all men again had improved $\mathrm{N}$ balance. In all cases, the level of $\mathrm{N}$ retention attained in this last period was greater than that in period 3 even though surfeit energy was presumably equal in both periods.

Stable period mean $\mathbf{N}$ balances (corrected for blood withdrawn), are represented in Table 6. Statistical analysis indicated significant subject-treatment interactions in the balance results, but comparisons among individual means showed that with few exceptions the change in individual mean $\mathrm{N}$ balance with treatment seemed to be similar man to man. 
During period 2, mean $\mathrm{N}$ balance was $-0.16 \mathrm{~g} \mathrm{~N} / \mathrm{d}$ when protein intake was $0.57 \mathrm{~g} / \mathrm{kg}$ body-weight per $\mathrm{d}$. Given the criteria mentioned previously as defining an $\mathrm{N}$ balance significantly different from zero, only three of the men (nos. 4201, 4202, and 4206) appeared to have been near $\mathrm{N}$ equilibrium during this period and two men (nos. 4203 and 4204) were not. There was a significant increase in $\mathrm{N}$ balance to $0.34 \mathrm{~g} \mathrm{~N} / \mathrm{d}$ with the addition of surfeit energy to the diet. The mean $\mathrm{N}$ balance when energy balance was re-established by increasing activity $(-0.02 \mathrm{~g} \mathrm{~N} / \mathrm{d}$ in period 4$)$ was not significantly different from that in the previous period, although there appeared to be a mean decrease in $\mathrm{N}$ retention of $0.36 \mathrm{~g}$ $\mathrm{N} / \mathrm{d}$. The $\mathrm{N}$ retention in this period with added activity was significantly increased (by $0.14 \mathrm{~g}$ $\mathrm{N} / \mathrm{d}$ ) over that in period 2 . When surfeit energy was added along with higher physical activity (period 5), the mean $\mathrm{N}$ balance increased by $0.89 \mathrm{~g} \mathrm{~N} / \mathrm{d}$. N retention in this last period $(0.87 \mathrm{~g} \mathrm{~N} / \mathrm{d})$ was significantly different from that in the third metabolic period, with equivalent surfeit energy.

TBK and lean body mass changes (Table 7) generally support the observations of $\mathrm{N}$ retention.

\section{DISCUSSION}

Von Liebig's (1842) postulation that protein is used as the primary energy source during strenuous physical activity has been rejected mainly on the basis that the energy equivalent of urinary urea excreted during or within the $24 \mathrm{~h}$ after an exercise bout is not sufficient to account for any great proportion of the total energy output (Fick \& Wislicenus, 1866; Astrand \& Rodahl, 1977; Rennie et al. 1981). Recent evidence using tissue culture preparations (Goldberg, 1969; Dohm et al. 1977) and labelled substrates in intact organisms (Lemon et al. 1980; Rennie et al. 1981; White \& Brooks, 1981; Young, 1981) indicates, however, that with long duration, high intensity activities, significant amounts of protein are metabolized (Lemon \& Nagle, 1981). Such transient or acute shifts in $\mathrm{N}$ metabolism are relevant to protein requirements only if they induce changes in the long-term $\mathbf{N}$ economy of the body. No evidence has been presented that the acute changes in protein catabolism triggered by physical activity continue after a brief adaptation period. Nor is there evidence as to whether or not those acute changes are countered by compensatory processes, resulting in no change in net protein catabolism. Long-term $\mathbf{N}$ balance studies would be necessary to examine these points. Few such experiments have been conducted, but there are several conclusions which can be drawn from available evidence.

First, when untrained individuals receiving energy intakes approximating need are started on a new exercise regimen, especially one which is strenuous and of long duration, there is a transient period of increased $\mathrm{N}$ loss (Molé \& Johnson, 1971; Gontzea et al. 1974, 1975) which may be minimized by increasing protein intake (Gontzea et al. 1974) or energy intake (Consolazio et al. 1975). After this initial period, urinary $\mathrm{N}$ decreases (Marable $e t$ al. 1979). Total $\mathrm{N}$ retention is ostensibly higher in individuals given higher protein intakes (Consolazio et al. 1975; Gontzea et al. 1974), yet careful examination of the information available suggests that change in $\mathrm{N}$ retention from control to experimental conditions may be no greater on higher than on lower $\mathrm{N}$ intakes (Conzolazio et al. 1975; Marable et al. 1979) and that the efficiency of retention of dietary $N$ (proportion of ingested dose retained) is markedly higher on the lower $\mathrm{N}$ intakes. The general consensus, based on these and other biochemical findings, has been that physically active individuals may require a greater protein intake to maintain $\mathbf{N}$ balance than do sedentary persons. However, our review of our own and other evidence suggests to us that chronic physical activity promotes an improvement in the over-all $\mathrm{N}$ economy and that, after some initial period of adaptation, the physically active individual consuming adequate energy to cover the increase in energy expenditure can maintain body protein better with more exercise than with less.

In the experiment reported here, physical activity was found to affect $\mathbf{N}$ metabolism in 
the following ways: (1) negatively, by increasing SN and FN losses; (2) positively, by requiring an increased energy intake which allows protein sparing; (3) by an effect of the physical activity itself on $\mathbf{N}$ retention. The cumulative effect of all these is to increase $\mathbf{N}$ retention of even a small protein intake $(0.57 \mathrm{~g} / \mathrm{kg})$ in the short-term in the more active individual.

Many investigators (Calloway et al. 1971; Consolazio et al. 1975; Lemon \& Mullin, 1980; Inoue et al. 1981) have considered sweat loss to be a major component of $\mathrm{N}$ balance. The total dermal loss in the present experiment $(290 \mathrm{mg} \mathrm{N} / \mathrm{d})$ is similar to that predicted by Calloway for equivalent work (318 N/d, Calloway et al. 1971). Mean SN for our entire experiment ( $4 \mathrm{mg} \mathrm{N} / \mathrm{kg}$ per d) was slightly higher than the $3 \mathrm{mg} \mathrm{N} / \mathrm{kg}$ per $\mathrm{d}$ assumed for integumental losses by FAO/WHO (1973) in predicting $\mathrm{N}$ requirements by the factorial method. It is markedly lower than the $15 \mathrm{mg} \mathrm{N} / \mathrm{kg}$ per d proposed by Garza et al. (1977 a) based on changes in total body ${ }^{40} \mathrm{~K}$ and creatinine excretion in young men on a low-protein diet, or the $13 \mathrm{mg} \mathrm{N} / \mathrm{kg}$ per $\mathrm{d}$ found by Inoue et al. (1981) in young sedentary men studied during the summer in Japan. Some investigators find a compensatory decrease in urinary $\mathrm{N}$ excretion in the presence of high SN loss (Bost \& Borgstrom, 1926; Ashworth \& Harrower, 1967) but others do not (Consolazio et al. 1963 b). For individuals exercising moderately while consuming a low-protein diet, $\mathrm{SN}$ may not be a major source of $\mathrm{N}$ loss. Nevertheless, failure to monitor SN in experiments involving physical activity and high-protein intakes could lead to confusion in results (Marable et al. 1979).

FN is considered by most investigators to be a constant in the $\mathrm{N}$ balance equation for any given individual on a given diet (Yoshimura, 1961; Molé \& Johnson, 1971). The response to increases in energy intake and increased physical activity varied from individual to individual in the present study and the magnitude of change was small. The possibility that physical activity affects FN excretion deserves further examination, but we believe the effect is more likely to be due to the increased food intake required to cover the cost of activity (Calloway, 1971).

The changes seen in these two factors, SN and FN, although small, suggest an increase in $\mathrm{N}$ need with physical activity. However, the $\mathrm{N}$ balance results (see Table 6 ) in which these factors have been included, support a general conclusion of improved $\mathbf{N}$ retention with physical activity.

In period 2, when the FAO/WHO (1973) safe level of protein was given in conjunction with energy sufficient to maintain body-weight, only one man (no. 4206) maintained both $\mathrm{N}$ equilibrium and constant body-weight. Other investigators (Garza et al. 1976, 1977b) also have found the FAO/WHO (1973) recommended protein intake to be insufficient to support $\mathrm{N}$ balance with presumably adequate energy intakes. This $\mathrm{N}$ intake will, however, support balance, given sufficient energy intake; all participants were in positive balance during the excess energy intake periods. This result is consistent with the body of literature showing that total energy intake is a major determinant of $\mathrm{N}$ balance (Calloway \& Spector, 1954).

The improvement in $\mathrm{N}$ retention accompanying the increase in energy intake in period 3 amounted to $0.29 \mathrm{mg} \mathrm{N} /$ added $\mathrm{kJ}$ ( $1.21 \mathrm{mg} \mathrm{N} /$ added kcal), whereas improvement in $\mathrm{N}$ retention associated with the increased energy intake in period 5 at higher activity level was $0.51 \mathrm{mg} \mathrm{N} /$ added $\mathrm{kJ}(2.1 \mathrm{mg} \mathrm{N} /$ added $\mathrm{kcal})$. Others have found that the efficiency with which increasing energy intake improves $\mathrm{N}$ balance diminishes with an increase in the extent of excess (Calloway, 1975; Rao et al. 1975; Garza et al. 1977a). Our findings suggest that the efficiency with which increasing energy intake improves $\mathbf{N}$ balance is increased in the presence of exercise.

Physical activity improved the utilization of marginal protein intake under both energy balance conditions. TUN and UUN were diminished and $\mathbf{N}$ retention increased despite 
slightly increased FN and SN losses in periods of increased physical activity (periods 4 and 5) compared with periods when activity was minimal (periods 2 and 3 ).

Improvement in $\mathbf{N}$ utilization in the presence of physical activity has also been found in young individuals. Viteri (1974) reported that in young rats given from 0.33 to 0.73 of ad lib. energy intakes for $32 \mathrm{~d}$, active animals accumulated $0.54 \mathrm{~g} \mathrm{~N} / \mathrm{g} \mathrm{N}$ given in comparison with $0.28 \mathrm{~g} \mathrm{~N} / \mathrm{g} \mathrm{N}$ given in inactive animals. Torun et al. (1975) found greater incremental increase in height and urinary creatinine and Young \& Torun (1981) reported increased $\mathrm{N}$ retention in children who were encouraged to be physically active as compared with sedentary children recovering from malnutrition.

The improvement in $\mathrm{N}$ retention with exercise seen in our experiment in the presence of both surfeit energy intakes and energy balance suggests that the protein requirement to maintain existing lean tissue in a chronically active individual may be somewhat less than that of one who is inactive. The apparent slight retention of $\mathrm{N}$ even with the marginal protein intake suggests that tissue is being laid down under these circumstances. This increase in tissue would theoretically continue until the size of the tissue mass was such that its turnover rate was just matched by the marginal protein intake. The positive $\mathbf{N}$ balances in period 5 seem to 'fall off' towards the end of the period (see Fig. 2) for several individuals (nos. 4201, 4202, 4205 and 4206), suggesting that this critical tissue mass may have been achieved. These individuals also stopped gaining weight at the end of period 5 (see Fig. 1). Body composition studies conducted were inadequate for predicting precisely the composition of tissue laid down during this experiment, but the mean values (Table 7) indicated that at least part of it was lean. This possible decrease in protein requirement with increased physical activity may be a consequence of the increased energy intake generally accompanying the activity or may be the effect of the activity itself.

The authors would like to thank the staff of the human metabolic unit for their assistance, and the men who volunteered for their outstanding co-operation in the performance of this experiment. This work was financed by grants from the National Institute of Health (AM 10202) and U.S. Public Health Service (AM 05511-5).

\section{REFERENCES}

Ashworth, A. \& Harrower, A. D. B. (1967). British Journal of Nutrition 21, 833-843.

Astrand, P. O. \& Rodahl, K. (1977). Textbook of Work Physiology, 2nd ed. New York: McGraw-Hill Book Co.

Bost, R. W. \& Borgstrom, P. (1926). American Journal of Physiology. 79, 242-244.

Calloway, D. H. (1971). Environmental Biology and Medicine 1, 197-202.

Calloway, D. H. (1975). Journal of Nutrition 105, 914-923.

Calloway, D. H. \& Margen, S. (1971). Journal of Nutrition 101, 205-216.

Calloway, D. H., Odell, A. C. \& Margen, S. (1971). Journal of Nutrition 101, 775-786.

Calloway, D. H. \& Spector, H. (1954). American Journal of Clinical Nutrition 2, 405-411.

Consolazio, C. F., Johnson, H. L., Nelson, R. A., Dramise, J. G. \& Skala, J. H. (1975). American Journal of Clinical Nutrition 28, 29-35.

Consolazio, C. F., Johnson, R. E. \& Pecora, L. J. (1963a). Physiological Measurements of Metabolic Functions in Man. New York: McGraw-Hill Book Co.

Consolazio, C. F., Nelson, R. A., Matoush, L. O., Harding, R. S. \& Canham, J. E. (1963 b). Journal of Nutrition $79,399-406$.

Coulombe, J. J. \& Faureau, L. (1963). Clinical Chemistry 9, 102-108.

Cuthbertson, D. P., McGirr, J. L. \& Munro, H. N. (1937). Biochemical Journal 31, 2293-2305.

Dohm, G. L., Hecker, A. A., Brown, W. E., Klain, G. L., Puente, F. R., Askew, E. W. \& Beecher, G. R. (1977). Biochemical Journal 164, 705-708.

FAO/WHO (1973). Energy and Protein Requirements. WHO Technical Reports Series no. 522 and FAO Nutrition Meetings Reports Series no. 52, pp. 48-53. Rome: FAO/WHO.

Fick, A. \& Wislicenus, J. (1866). Philosophical Magazine 31, 485-503.

Garza, C., Scrimshaw, N. S. \& Young, V. R. (1976). American Journal of Nutrition 29, 280-287.

Garza, C., Scrimshaw, N. S. \& Young, V. R. (1977a). Journal of Nutrition 107, 335-352.

Garza, C., Scrimshaw, N. S. \& Young, V. R. (1977b). British Journal of Nutrition 37, 403-420. 
Goldberg, A. L. (1969). Journal of Biological Chemistry 244, 3217-3222.

Gontzea, I., Sutzescir, P. \& Dumitrache, S. (1974). Nutrition Reports International 10, 35-43.

Gontzea, I., Sutzescir, P. \& Dumitrache. S. (1975). Nutrition Reports International 11, 231-236.

Inoue, G., Fujita, Y. \& Niiyama, Y. (1973). Journal of Nutrition 103, 1673-1687.

Inoue, G., Yamamoto, T. \& Kishi, K. (1981). In Protein-Energy Requirements in Developing Countries: Results of Internationally Coordinated Research [W. M. Rand, R. Vany and N. S. Scrimshaw, editors]. United Nations University.

Kirk, R. E. (1968). Experimental Design: Processes for the Behavioral Sciences. Belmont: Brooks/Cole Publishing Co.

Kurzer, M. S. \& Calloway, D. H. (1981). American Journal of Clinical Nutrition 34, 1305-1313.

Lemon, P. W. R., Benevenga, N. J., Nagle, F. J. \& Mullin, J. P. (1980). Medicine and Science in Sports and Exercise 12, 133 (Abstract).

Lemon, P. W. R. \& Mullin, J. P. (1980). Journal of Applied Physiology 48, 624-629.

Lemon, P. W. R. \& Nagle, F. J. (1981). Medicine and Science in Sports and Exercise 13, 141-149.

Marable, N. L., Hickson, J. F. Jr, Korslund, M. K., Herbert, W. G., Desjardins, R. F. \& Thye, F. W. (1979). Nutrition Reports International 19, 795-805.

Molé, P. A. \& Johnson, R. E. (1971). Journal of Applied Physiology 31, 185-190.

Rao, C. N., Naidu, A. \& Rao, B. S. (1975). American Journal of Clinical Nutrition 28, 1116-1121.

Rennie, M. J., Edwards, R. H. T., Krywawych, S., Davies, C. T. M., Halliday, D., Waterlow, J. C. \& Millward, D. J. (1981). Clinical Science 61, 627-639.

Siri, W. E. (1966). University of California Radiation Laboratory, Report no. 3349, Donner Laboratory of Biophysics and Medical Physics.

Torun, B., Schutz, Y., Bradfield, R.\& Viteri, F. E. (1975). Eleventh International Nutrition Congress Kyoto, Japan, p. 29.

Torun, B., Scrimshaw, N. S. \& Young, V. R. (1977). American Journal of Clinical Nutrition 30, 1983-1993.

Viteri, F. E. (1974). In Nuevos Conceptos Sobre Viejos Aspectos de la Desnutricion Academia Mexicana de Pediatria Mexico: La Academia Mexicana de Pediatria, pp. 207-229.

Von Liebig, J. (1842). In Animal Chemistry or Organic Chemistry in Its Application to Physiology and Pathology [W. Gregory, translator]. London: Taylor \& Walton.

White, T. P. \& Brooks, G. A. (1981). American Journal of Physiology 240, E155-E 165.

Wilmore, J. H. (1969). Journal of Applied Physiology 27, 96-100.

Yoshimura, H. (1961). Federation Proceedings 20, 103-110.

Young, V. R. (1981). In Biochemistry of Exercise: Exercise and Hormone Regulations, pp. 59-74 [J. Poortmans and G. Nisel, editors]. Baltimore: University Park Press.

Young, V. R. \& Torun, B. (1981). In Nutrition in Health and Disease and International Development: Symposia From the XIIth International Congress of Nutrition, pp. 57-85. New York: Alan R. Liss, Inc. 